International Journal of Biological Research, $2(2)(2014) 143-144$
International Journal of Biological Research
JPC \begin{tabular}{c} 
Journal home page: $\begin{array}{c}\text { www.sciencepubco.com/index.php/IJBR } \\
\text { do.14419/ijbr.v2i2.3591 } \\
\text { Research Paper }\end{array}$ \\
\hline
\end{tabular}

\title{
Nervous form of ketosis in cows and its treatment
}

\author{
B. Sudhakara Reddy ${ }^{1 *}$, B. Soma Sekhar Reddy ${ }^{2}$, Y. V. Pridhvidhar Reddy ${ }^{3}$, R. Vennkatasivakumar ${ }^{2}$ \\ ${ }^{1}$ Assistant Professor (Veterinary Medicine), Teaching Veterinary Clinical Complex \\ ${ }^{2}$ Assistant Professor, Dept. of Veterinary Medicine \\ ${ }^{3}$ Assistant Professor, Dept. of Veterinary Gynaecology and Obstetrics \\ College of Veterinary Science, Sri Venkateswara Veterinary University, \\ Proddatur-516360, Y.S.R.District, Andhra Pradesh, India. \\ *Corresponding authorE-mail: bhavanamvet@gmail.com
}

\begin{abstract}
Ketosis is defined as an abnormal rise of the ketone or acetone bodies in the body. The ketone bodies are organic chemical compounds and include acetone, acetoacetic acid, and beta hydroxy butyric acid. Present study reports the primary nervous ketosis in three cows at their peak milk yield. Cows exhibited the bellowing, head pressing and reluctance to take concentrates. Low serum glucose, high levels of blood urea nitrogen with ketonuria was observed. Cows showed fruitful recovery after treatment with $25 \%$ glucose solution, dexamethasone and glycerin along with supportive therapy.
\end{abstract}

Keywords: Cows, Dextrose, Ketosis, Nervous Signs.

\section{Introduction}

Ketosis is a common metabolic disorder in high yielding dairy cows. During peak lactation period, high yielding dairy cows enter a stage of negative energy balance due to energy output required for milk production is higher than the energy obtained from the consumed feed. Due to negative energy balance there is decrease in serum concentration of glucose and insulin that will inturn leads to mobilization of adipose tissue with which consequently increases serum concentrations of non-esterified fatty acids (NEFA) and beta hydroxy butyric acid (BHBA) (Radostits et al. 2000).

Bovine ketosis is expressed in two forms of which most common one is wasting form and another form is nervous form which is a rare expression. Many reports regarding the wasting form of ketosis and subclinical ketosis were recorded (McArt et al. 2012). But, very little information was available on nervous form of ketosis (Wootton 1992). Hence, present communication reports primary nervous ketosis in dairy cows.

\section{Materials and methods}

During the six months period of observation at Teaching Veterinary Clinical Complex, Ambulatory clinic in College of Veterinary Science, Proddatur, three cows were identified suffering with acute onset of nervous signs like bellowing, crossing of the forelegs while walking, circular movements and anxiety. All the three cows were calved 50 to 70 days back, reluctance towards concentrate feed, presence of dry faeces, dull rough hair coat, sudden drop in milk yield. Among the three one cow occasionally used to push towards walls, severe jaw movements and salivation.

Clinical examination of the cows revealed normal temperature ( 101.4 to $\left.102.1^{\circ} \mathrm{F}\right)$, respiration rate $(21$ to $28 / \mathrm{min})$, higher heart rate (82 to $99 / \mathrm{min}$ ), ketotic odour on their breath, ruminal hypomotility (2/6min), hyperesthesia and severe excitation.

Genital tract was normal with smooth inactive ovaries and slight doughy rumen on per rectal examination. Whole blood, serum, urine and milk were collected for laboratory examination. Blood sample were collected from jugular vein with sterile disposable syringe and $1 \mathrm{ml}$ of blood was transferred in to vacutainer containing EDTA and $4 \mathrm{ml}$ of blood was transferred into the vacutainer without anticoagulant coated with clot activating factor. Serum was separated for biochemical analysis. EDTA blood was subjected to complete haemogram and for screening against blood protozoans (Reddy et al. 2014a; Sivajothi et al. 2014a). Serum sample was analyzed for glucose, total protein, albumin, calcium and blood urea nitrogen. Urine and milk samples were also screened with rothera's test. Faecal samples were screened for the parasitic ova by sedimentation technique. Urine samples were tested using uristix examination for other abnormalities.

\section{Results and discussion}

Haematology did not reveal any significant changes in the present study. Observed haematological parameters under the normal range of local values recorded in the previous studies (Sivajothi et al. 2014b). Faecal samples and whole blood did not reveal any parasitic ova and haemoprotozoan diseases respectively.

Serum biochemical analysis had decreased levels of glucose $(29 \mathrm{mg} / \mathrm{dL})$ and calcium $(8.4 \mathrm{mg} / \mathrm{dL})$. Normal serum albumin $(2.1 / \mathrm{dL})$, total protein $(6.3 \mathrm{~g} / \mathrm{dL})$ and increased blood urea nitrogen $(98 \mathrm{mg} / \mathrm{dL})$ levels were recorded. Urine was positive rothera's test and presence of ketone bodies were recorded in uristix examination. Case was diagnosed as primary nervous form of ketosis.

Fruitful recovery was obtained after treatment with intravenous administration of $25 \%$ glucose solution for three days (@5 $\mathrm{ml} / \mathrm{kg}$ body weight), intra muscular administration of dexamethasone (@ 
$0.1 \mathrm{mg} / \mathrm{kg}$ body weight) for two days, oral administration of 200 $\mathrm{ml}$ glycerin for five days. Further, owner was advised to give oral liquid containing nicotinamide and cyanocobalamin (E-booster) $100 \mathrm{ml}$ twice daily up to 10 days. On the $3^{\text {rd }}$ day of treatment there is slight improvement in behavioral signs and urine was negative for ketone bodies.

The most critical time in the life of a dairy cow is the first few days postpartum during which the cow is most susceptible to metabolic disorders and some diseases. Many of the disorders occurring in the early lactation increase the risk of diseases later during the current (Reddy et al. 2014b). Ketosis is a metabolic disorder that is characterized by elevated concentrations of ketone bodies in blood, urine and milk. Primary ketosis is due to a primary energy deficiency in high milk producers. Ketone bodies arise when ketone production begins to exceed consumption. The heavy demands of early lactation can cause persistent hypoglycemia with resultant decrease in insulin production and subsequent lipid mobilization. The resulting hepatic lipidosis can compromise liver function. Hepatic ketogenesis increases and hypoglycemia and hyperketonemia occur. Hypoglycemia, hyperketonemia and elevated serum concentrations of isopropyl alcohol have all been suggested as the cause of nervous signs (Foster 1988). However, starved cows that are also hypoglycemic and hyper ketonemic do not exhibit nervous signs. The difference may be in the ratio of acetoacetate to, beta-hydroxy butyrate levels in nervous ketosis.

Ketosis can either be a primary condition (due to an incapacitation of the liver to produce glucose) or a secondary condition, due to diseases and disorders followed by a reduced feed intake. Ketosis is followed by a reduced milk yield, reduced reproductive performance, metritis and displaced abomasums, and therefore the disease is very costly to the dairy industry (Ingvartsen 2003). Predisposing factors for development of ketosis was due to over feeding before calving, underfeeding during lactation, inadequate exercise, and the feeding of silage with high butyric acid content. Present observed serum biochemical findings in association with the findings of pregnancy toxaemia recorded in the ewe (Jothi et al. 2014). Observed nervous signs were associated with higher BUN levels (Reddy and Kumari 2011). Previously nervous ketosis in a she buffalo due to primary ketosis was reported (Upadhyay et al. 2007). In the treatment glycerol was given which will be converted to glucose in the liver of cattle. Glycerol enters the gluconeogenic pathway at the level of dihydroxyacetone phosphate and 3-phosphoglyceraldehyde. This is several biochemical steps closer to glucose than the traditional gluconeogenic precursors, propionate and propylene glycol.

Present condition can be differentiated with other neurological disorders that can cause nervous signs in cows. Based on the nervous signs, hypoglycemia, ketonuria and response to the therapy condition was confirmed as nervous form of ketosis in cows.

\section{Conclusion}

In the present study reports the primary ketosis in cows at their peak milk yield, with sudden drop in milk yield and showing the nervous signs like bellowing, circular movements and hyperesthesia.

\section{Acknowledgement}

Corresponding author expressed his thankfulness to the Dr.Saradmma, Assistant Director, Proddatur. Authors are thankful to Sri Venkateswara Veterinary University for providing facilities to carry out this work.

\section{References}

[1] Foster LA. Clinical ketosis. Veterinary Clinics of North America: Food Animal Practice, 1988; 4: 253-265.

[2] Ingvartsen LL, Kjærgaard M, Nielen N, Børsting CF, Weisbjerg MR, Larsen $\mathrm{T}$ (2001) Variation in and relationship between ketone bodies and metabolites in blood and milk during early lactation. Internal re- port prepared for Lattec I/S. Danish Institute of Agricultural Sciences, $18 \mathrm{pp}$.

[3] Jyothi K, Reddy BS, Reddy YVP, Rao KP, Sivajothi S, Ganesan A (2014) Pregnancy toxemia associated with Dystocia in a Nellore Brown Ewe. Pelagia Research Library Advances in Applied Science Research, 2014, 5(3):325-327.

[4] McArt JAA, Nydam DV, Oetzel GR (2012) Epidemiology of subclinical ketosis in early lactation dairy cattle, Journal of Dairy Science, 95 :5056-5066http://dx.doi.org/ 10.3168/jds.2012-5443.

[5] Radostits OM, Blood DC, Gay GC (2000) Veterinary Medicine. A Textbook of the Diseases of Cattle, Sheep, Pigs, Goats an Horses. W.B. Saunders. PP: 1452-1462. Veterinary Medicine. 9th Edn. ELBS, Bailliere and Tindall, London

[6] Reddy BS, Kumari KN (2010) Therapeutic Management of Alkaline Indigestion in Bovines - A Report of Three Cases. Intas Polivet, Vol. 11 (II): 173-174.

[7] Reddy LSSVP, Reddy BS, Naik BR , Prasad CS (2014a) Haematological and clinical alterations with traumatic reticuloperitonitis in cattle. International Journal of Veterinary Science, 3(4): 203-205.

[8] Reddy BSS, Kumari KN, Reddy YR, Reddy MVB, Reddy BS (2014b) Comparison of different diagnostic tests in subclinical mastitis in dairy cattle. International Journal of Veterinary Science, 3(4): 224228.

[9] Sivajothi S, Rayulu VC, Reddy BS (2014a) Detection of Trypanosoma evansi by different methods in bovines in Andhra Pradesh. The Journal of Advances in Parasitology, 1(3):35-38. http://dx. doi.org/10.14737/journal.jap/2014/1.3.35.38

[10]Sivajothi S, Reddy BS, Kumari KN, Rayulu VC (2014b) Haematological changes in Trypanosoma evansi infected cattle. International Journal of Scientific World, 2(1):27-30. DOI: 10.14419/ijsw.v2i1.2275.

[11]Upadhyay SR, Sharma N, Pandey V (2007) Nervous Ketosis in Buffalo - A Case Report, Intas Polivet, Vol. 8 No. II: 404-406.

[12]Wootton P (1992) Nervous ketosis, Canadian Veterinary Journal, Mar, 33(3): 194. 